\title{
19
}

\section{Reflecting and Writing About Our Teaching}

Mark Weisberg

Queen's University

Reflecting on what we are doing can help us become better teachers and better people; yet in our increasingly busy and stressful lives, how can we find the space and time? This chapter describes and exemplifies two strategies that can help us and our colleagues become more reflective about our teaching and about our vocation: the Teachers' Reading Circle, meeting for regular discussions of provocative texts about teaching and learning, and the Teachers' Writing Circle, using prompts and examples of colleagues' writing to set participants on an extended course of writing about their own teaching.

T's 8:30 on a foggy October morning in Portland, Oregon. Twelve university Iteachers are gathered at four small round tables. They have come to reflect on and write about their teaching. It is a diverse group: in age, in experience, in academic discipline, in ethnic origin. Yet as they introduce themselves, explain why they are in the room, it's as if they speak in one voice: "No time," that voice says. "I want to reflect and to write, but I don't have time." "Too busy, too many obligations, at work and at home." "Too stressed; stretched too thin." "We have 3.5 hours; I'm hoping to find some inspiration."

They are not alone. These teachers are expressing what seems to be a constant in academic life. Many feel rushed, scattered, careening from email to meeting to class to crisis throughout the day, and consequently, unable to do what they most want to do. They yearn for time and space to reflect on their experiences, to learn from them and grow, occasionally at least, and even better, regularly. How to respond to this yearning? 
As a teacher in a professional school, $I$ have felt it crucial for students to reflect on what it might mean to lead an ethical life in law or in medicine and to carry that reflective practice into their working lives. I have tried to build into my courses structured opportunities for reflection, such as journal writing in and out of class, moments of silence, and provocative readings. And as a person working in faculty development, I've wondered how to offer colleagues similar opportunities.

One obvious way would be to facilitate extended reflection retreats, three or four days, enough time for people to become comfortable with each other and to establish a rhythm, and enough space for both individual and group reflection. I have co-facilitated three of these, and they work extremely well for people able to commit that much time and with resources to travel to a location conducive to reflection. Most participants have reported returning home with renewed energy for teaching and with a plan for building reflection into their lives.

Not everyone has that time and those resources. So for shorter periods, especially when working within a single university, I have found two approaches particularly promising. One is the Teachers' Reading Circle, monthly meetings focused on a provocative text about teaching and learning. Examples have included Mary Rose O'Reilley's books The Peaceable Classroom (1993) and Radical Presence (1998); Don Finkel's Teaching With Your Mouth Shut (2000); Parker Palmer's The Courage to Teach (1998); Jane Tompkins's A Life in School (1996); and Peter Elbow's Embracing Contraries (1986). Sessions typically are 1.5 hours. Before coming, participants will have read an assigned section of the book, or an article. The person facilitating might offer a prompt to help open the conversation, but after that, discussion remains relatively unstructured but always lively, as participants offer their responses to the readings and bring their own experiences into the room. Often isolated in their own departments, participants find a community of colleagues eager to listen to their experiences and perspectives and eager to share their own. And although enrollment has been limited, the series has been successful, running continuously for the past seven years.

The other approach involves a companion to the Teachers' Reading Circle -the Teachers' Writing Circle. Here the goal is to combine reflection with writing, to set participants on an extended course of writing about their teaching. Sessions might begin with the facilitator reading from one or two examples produced in similar sessions, or even examples of student writing (Allen, 1989). If someone would like to read from their own work, we would begin with that. Whereas hearing or reading examples from successful writers can overwhelm someone trying for the first time to write about his or her teaching, I have found that when writers experience what their peers can do, they feel encouraged to risk trying themselves. That approach certainly has 
worked with law students in my Legal Imagination class, eight of whom recently had their expressive writing published in a journal typically devoted to faculty work (Weisberg, 2003). It also has worked in writing workshops I've attended, two of which led to the publication of a book of pieces by national teaching award winners (Lerch, 2005), many of whom had attended one of these workshops and were sufficiently encouraged by their experience and by their colleagues' reception of their work to submit it for peer review.

In the workshop I'm describing, which occurred at the 2006 Professional and Organizational Development Network in Higher Education conference, colleagues have come both because they want time to write and reflect, and because as faculty developers they are interested in offering similar opportunities to their colleagues at home. Consequently, I have combined these two approaches, the Teachers' Reading Circle and the Teachers' Writing Circle.

We begin with an exercise designed to warm up our thinking and writing muscles:

In front of you is a sheet with five quotations, each taken from a different book. Please read them through, find one that resonates for you, positively or negatively, and spend some time writing about it. I'll give you about eight minutes.

\section{White Space}

It requires a long time to take in a few words.

On either side of the word we need a patch of white, of silence, like the white space that defines a Chinese painting, or the rests in music that permit the notes to be heard.

By and large, our students are relentlessly over stimulated. They sing the body electric: plugged in, tuned out, motorized. And we are over stimulated, too. Many of us hate silence, especially in the classroom. It is the teacher's ultimate nightmare: what if I can't fill fifty minutes? And yet, if students spend twenty minutes in silence looking at ten lines of Homer, it can be time well spent.

I heard a student talking the other day about the difference between two sociology professors. "I love Professor Jones. He lectures from the moment he enters the room, without ever looking at his notes. You really get your money's worth in there. I don't know about Professor Smith. Sometimes you ask him a question and he looks out the window for a while before he answers." 


\section{An Experiment in Friendship}

Attention: deep listening. People are dying in spirit for lack of it. In academic culture most listening is critical listening. We tend to pay attention only long enough to develop a counterargument; we critique the student's or the colleague's ideas; we mentally grade and pigeonhole each other. In society at large, people often listen with an agenda, to sell or petition or seduce. Seldom is there a deep, openhearted, unjudging reception of the other. And so we all talk louder and more stridently and with a terrible desperation. By contrast, if someone truly listens to me, my spirit begins to expand.

\section{The Teacher Within}

When we listen primarily to what we ought to be doing with our lives, we may find ourselves hounded by external expectations that can distort our identity and integrity.... In contrast ... Frederick Buechner offers a more generous and humane image of vocation as "the place where your deep gladness and the world's deep hunger meet."

In a culture that sometimes equates work with suffering, it is revolutionary to suggest that the best inward sign of vocation is deep gladness-revolutionary but true. If a work is mine to do, it will make me glad over the long haul, despite the difficult days.... If a work does not gladden me in these ways, I need to consider laying it down.

\section{The Cloister and the Heart}

Human beings, no matter what their background, need to feel that they are safe to open themselves to transformation. They need to feel a connection between a given subject matter and who they are in order for knowledge to take root. That security and connectedness are seldom present in a classroom that recognizes the students' cognitive capacities alone. People often assume that attention to the emotional lives of students, to their spiritual yearnings and their imaginative energies, will somehow inhibit the intellect's free play, drown it in a wash of sentiment, or deflect it into realms of fantasy and escape, that the critical and analytical faculties will be muffled, reined in, or blunted as a result. I believe the reverse is.true.

\section{The Danger of Softness}

Teachers teach who they are as much as what they know. 
"Would you please turn to a colleague and share with him or her whatever you'd like to share about what you've written."

A palpable buzz fills the room. People are reading what they wrote, engaged in intense discussion. Participating myself, I hear several incredible stories, beautifully expressed-people in midlife beginning new careers in faculty development, some doing so amid considerable personal stress, others wondering whether teaching really is their vocation and whether they should lay it down. The depth of personal revelation is startling, and refreshing.

Several respond to "White Space," noting how little of it is present in their teaching or collegial relations, and even in their lives. They want more, will try for more. This theme is often repeated in reflection workshops and in participants' evaluations.

Many volunteers contribute to the discussion, and more want to talk. To write is to commit, and when people have made those commitments, they're typically more willing, often anxious, to reveal them. We could continue discussing, but I want to suggest other strategies, allow people to experience them.

"In your materials you'll find a chapter from Mary Rose O'Reilley's book Radical Presence. I'd like to invite us to read it aloud, paragraph by paragraph. If someone would be willing to start us off, we can proceed-to make things easier, perhaps in a circle. The passage begins with the third paragraph on page 40."

Reading aloud in this fashion is a way of getting everyone's voice into the room. While scary, it is less threatening to most people, and usually more productive, than asking for a quick verbal response to a question or a prompt. As Peter Elbow (1986) puts it, "If you want to get people to seem dumber than they are, try asking them a hard question and then saying, "Now think carefully"' (p. 56). Of course, one needs to be sensitive to those whose first language isn't English or who are unable to read.

Here is part of O'Reilley's (1998) passage:

Some years ago I spent a sabbatical in a contemplative Quaker community that pretty much unfitted me for the academic world I had left behind. When I came back to my university, I was as confused and befuddled as some kind of alien from a neighboring galaxy....

The problem was, nothing I had learned on sabbatical had fitted me to sit at a desk. In fact, I had not come back from sabbatical. Someone had come back, but it was not the person who had left....

I tried very hard to do the work left behind for me by this woman who had gone away and not come back, but the harder I tried, the more I became physically or metaphysically ill. That woman, the for- 
mer inhabitant of my body, lectured four days a week, three hours a day, just like her colleagues up and down the hall. When I opened my mouth to deliver her lectures, my chest started to hurt and a smothering sensation came over me. I ran out of breath and got faint. It has nothing to do with "getting used to it again," as my helpful colleagues suggested. I just didn't believe the words I was expected to deliver, and my vocal apparatus refused to make the sounds.

I was no longer able to tell my students what they needed to know, because I didn't know what they needed to know, though only a year ago, I had been quite sure.

What are you doing? What are you really doing? What is your deepest sense of call, your true vocation? My "consultant" (something like a spiritual director) in the contemplative community had asked me these questions week after week, and I had a vague answer. To listen, whatever that might mean. To find out what it might mean. On reentry into this galaxy, I quickly became aware of what it did not mean: lecturing on Joseph Conrad, schmoozing at academic cocktail parties. These activities and a few others (some of which were contractual obligations) brought on symptoms that felt like a heart attack. Heart break, maybe. It's easy for me to resist my deepest sense of call, especially if the call interferes with my ambitions about making a living and gaining prestige. ... I was confused about priorities, about what I was supposed to be doing... and I was going home every day feeling that, no matter what I had accomplished, I had not done the right thing.

Somewhere in the middle of this crisis, the idea of composing a job description for myself occurred to me. I decided to write down a sentence that reflected my clearest sense of the task. Then I could feel that, whatever else got screwed up, I had been faithful to some inner light. Peaceful listening, I wrote on a three-by-five inch card, and tacked it up over my desk. The phrase helped me pull my days together. When all the phones were ringing, committees meeting, students lining up, I could tell myself, "The only thing that needs to happen is peaceful listening." This turned out to be a useful role for me. Since not too many people were listening to anybody, ever, around the university, I could take up a little slack. (pp. 40-42)

How would you respond to O'Reilley's invitation to compose your job description? How would your colleagues respond? What would a university look like if faculty members could collaborate on writing their job descriptions? Even if not individually, then collectively. 
I have been challenged and intrigued by this thought experiment since I first encountered it several years ago. Here's my latest effort:

Giving permission, or better, encouraging my students to give themselves permission. Permission to bring yourself to your work, to step forward, to risk being present in what you write and what you say. Permission to care. Permission to take your classmates and yourself seriously, as writers, as thinkers, as individuals responsible for the shape of the law. Permission to set your own goals and see what it might mean to work toward accomplishing them. (Weisberg, 2003, p. 435)

In the final segment of our workshop, I wanted to offer everyone an extended time to write, at least 20 minutes. Following Guy Allen's example (1989), I read two stories (reproduced in Appendix 19.1), powerful examples of expressive writing, one produced by a colleague in a similar writing workshop that later was published in Making a Difference (Connolly, 2005), the other by a law student, which begins with her discovering in class that the murder case in front of her that bears her family name is in fact about her father (Munro, 2003). What follows is an extraordinary meditation on her family, her fractured place in the legal world, expressing simultaneously what often is missing in legal adjudication: the people and their emotional lives.

Before setting everyone to work, I also stress how important it is for a writer to be detailed, not to hide behind abstractions, as academic prose often encourages us to do. As Natalie Goldberg (1990) reminds us,

Be specific. Not car, but Cadillac. Not bird, but wren. Not fruit, but apple. Not a co-dependent, neurotic man, but Harry, who runs to open the refrigerator for his wife, thinking she wants an apple, when she is heading for the gas stove to light her cigarette. (p. 3)

And later:

Mies van der Rohe, a twentieth-century architect, said God hides in the details. It is important as a writer to stay in the trenches with the details and not jump out because it is too scary to be there. Denial, repression, all those psychological adaptations we developed in childhood, were ways of not being there. Writing demands that we cut through and be where we are, and like a cat gripping the side of a cement wall at the top of a ten story building, stay there and look around and not blank out because it is too hard. This is it, here, whatever comes up. (p. 203) 
I add, "You might want to write about a teaching or learning experience, positive or negative, a critical incident in teaching and learning, for example, a problem with a student or colleague. Or you might want to ask yourself this provocative question: What if I had nothing to prove? If that were true, what would my teaching and my personal life look like? We spend so much of our time and energy responding to and allowing ourselves to be controlled by real or imagined external demands, and trying to show ourselves worthy, that it might be interesting to reflect on what life would be like were we to give that up."

Twenty minutes later, several people still are writing. After several more minutes, they look up, and I invite people to read what they'd written. One person, who had published poetry years before but recently had been too busy to do so, found himself writing a poem. Another wrote this poem:

\section{what if $i$ had nothing to prove?}

i wouldn't wear so much black

i wouldn't rush to get to work on time

i wouldn't worry that i haven't cleaned out my car since i don't know when

i wouldn't worry what my neighbors think when i sit on the driveway with

my daughter on a cold October evening rolling chalk back and forth

i wouldn't worry about faculty who criticize the readings i hand out at the lilly seminar

i wouldn't care when you-know-who sizes up the clothes i'm wearing i wouldn't worry that my daughter is addicted to Elmo and will grow to hate reading i would not wax facial hair

$i$ would be more relaxed

$i$ would be the envy of the world

i would never have to update my CV

i would work on my novel instead of trying to find the perfect job i would not worry if my dahlia tubers don't get dug up before they freeze $i$ would not feel it necessary to put Ph.D. on my e-mail signature -Justine Dymond

Reprinted with permission.

Funny, and also telling. In universities, and elsewhere, we tend to measure our success comparatively. Our differential salaries reflect external judgments 
of our "merit." We compete against each other for a fixed pool of financial resources. We measure ourselves by our success in being published in the most prestigious journals. And we pass that competitiveness on to our students. As Mary Rose O'Reilley (1993) puts it: "That's what teaching should be about ... discerning the gift. Too often, by contrast, the central discipline of our craft is judging" (pp. 90-91). We discern the gifted, not the gift.

If we can give up that need to justify our lives to others, we might become more relaxed, less competitive, might not postpone writing the novel we yearn to write or the article we've avoided for fear our colleagues won't approve. Instead of having time as our enemy as we rush to work, we might make time our friend. Rather than ranking ourselves and each other, we might become freer to recognize, enjoy, and feel enriched by each person's gifts, and in the process become better teachers and better colleagues.

Hearing several colleagues read, another person volunteered, reporting that initially he had decided not to read because what he wrote was too personal. However, having experienced several equally personal pieces, he read his, in which he was concerned that in his research he had been neglecting the global issues he cared most about. The session had moved him to think seriously about how he was pursuing his vocation.

Another participant was encouraged by hearing others and also decided to share what she'd written. Let me share it with you.

Why Am I So Bothered About Class Attendance?

Dear Class,

I have been thinking long and hard about your poor attendance in class and why it bothers me so. I really have and now here I am in Portland at a teaching conference and l've been given 20 minutes to write. Oh, and to write reflectively. My first impulse was to write a lecture for Monday. I want to update that topic and am worried about when I'll have the time as I get back late on Sunday. Well, that's not really reflective and it was leading to cynical thoughts of why bother, half of you won't be there anyway!

That led me back to why the heck do I care? I get paid either way. The students getting As and Bs are always there. Is it that I have this great need to be important in your life? I don't think so. Oh, ok, a teensy bit. I like you. I don't even know you. The ratio in lecture is 178 to 1 and I'm not good with names and faces. But I do like you! You represent the very best of what life can be and you are at a wonderful passage in your life. And the bummer is, that some of you don't have the time to enjoy that. Your life stinks, you're angry or you're just too 
busy. I like you and care for you because you are 20-something and about to passage into the rest of your life. And, I know for some of you your performance in this class can make or break that event. And I figure some of you are angry and pissed off that this class is hard and requires work.

And that truly bothers me! You're seniors in majors that require this course and something has gone terribly wrong. And not just with you, but I fear with this institution or hell, with our whole society.

Here you are seniors and either you've reached this point without developing the learning skills needed to succeed or you've given up. That is the fault of the institution. Or, you're just here to get the degree and gee darn, now you're in a bit of a pickle, but you don't have the discipline to fix it.

Either way, that's what really, really bothers me-you are so damn disengaged. Whatever its cause this is the true heart of the matter and the challenge to me-To engage you!

And yet, I'm not sure how best to do this. What I must tell you regardless of how I tell you is that you're not working hard enough. And no one wants to hear that. I'm willing to soften the message and tell you that I'll help you with this. It's true and I will. Or am I just a push over and I need to tell you-get off your lazy butts and do it or you'll flunk. That's apparently what football coaches do at halftime and then the team goes out and wins. Well, I will take the former path if I speak of this to the class at all.

So, on Monday I'll lecture as I always do, even if you don't come. I can't help myself. I am compelled. There is a beauty to this subject that I can't help but share. And I think that is what bothers me the most when you don't come. You miss the beauty.

-Sharon Roberts

Reprinted with permission.

As these pieces demonstrate, with time and space to entertain it, and a willingness to set pen or pencil to paper and write continuously, a prompt such as "nothing to prove" can liberate the imagination, invite you to think beyond your usual constraints about your vocation. What you discover may be uplifting; it may be discouraging; it's likely to be challenging; and I hope it may set you on a path toward continuing reflection.

Working with the prompts I've described here and with others I've used or experienced (Peters \& Weisberg, 2005), such as inviting participants to write their obituary or the eulogy for their funeral, what they'd like to have 
said about them at the end of their life, or invoking Saakvitne and Pearlman's (1996) invitation to visit their future self through a meditation featuring guided imagery, has affected many participants deeply, and in some cases led them to make radical changes in their teaching (Weisberg \& Peters, in press).

Although our Portland workshop was relatively brief, the participants responded similarly. Asked what was most valuable about the session, they wrote, "The prompts were wonderful, really got us going." "Writing; hearing others." "Being able to write and knowing that I can write and that other people will read and are interested in my writing." "Thought provoking readings. Excellent framework for writing. Wonderful colleagues." These comments confirm my own experience that there are many people who will welcome the opportunity to write about and reflect on their teaching. They don't need much encouragement: someone willing to help them get started and one or two well chosen prompts, of which those I've mentioned here are only examples. If one or two people are willing to share their work, the rest may take care of itself.

I hope you can see the possibilities for reflection that these two approaches offer and that some of you will be tempted to try versions of them as facilitators in workshops with your colleagues, as a participant together with others similarly interested, even alone. There are many fascinating stories to be told and heard, and telling and hearing them can begin to provide the space and time many of us need. 


\section{Appendix 19.1 \\ Two Stories}

\section{A Family's Criminal Legacy}

\section{Tanya Munro}

I took a deep, unsettling breath. My throat seized. I swallowed hard and tried to force stalled pockets of air into my lungs. Even to inhale required concentration. Greasing my fingers with saliva, I flipped through the pages of my first-year criminal law book. My pulse quickened and I dropped my chin closer to the book to disguise the spreading color on my face, as I quietly prayed against the inevitable. Believing that god overlooked me, I have never been a religious person. Yet I hoped. My pleas for concealment were bargained without faith and proved futile. There it was, $R$. v. Munro and Munro broadcast in bold black ink. I stared at my name, branded on page 404 . I wanted to escape my skin. MUNRO. Munro, my new, inexorable, and apparently unavoidable identity. A dispassionate judicial narration of my bloodline was here casually exposed in print, my family legacy succinctly summarized in two pages. Carswell, the book publisher, had resurrected my history and distributed it en masse to the entire law school community. What I felt most was fear and shame, thoroughly humbled by my "white trash" origins. I did not consider infamy to be flattering attire for professional school. Would I have to submit to autograph signings after class?

I expected my fellow students to find me guilty by association, that my presence in law school had smudged that imaginary line between "good guys" and "bad guys." Smart, educated, good people go to law school. Law students are borne from doctors, philanthropists, accountants, teachers, and other lawyers. They are not descended from callous murderers, rapists, and common thieves. Law students read about criminals; they don't share DNA with them. I had become a double agent, caught in the big lie. My secrets unveiled, broadcasted, and scrutinized...

I found it to be an odd experience, to read about my family from a stranger's perspective. First, I noticed that judicial ink indifferently stamps names and describes events. The real people are vacant from the sober presentation of case law. In a legal rendition of life there are no fathers, uncles, or daughters, no broken homes or beaten spirits. There are no stories of children kissing their father through walled prison plastic, or a child's silly preference for jails with vending machines that have their favorite candy. The pallid pages of the law books recite blunted facts and dramatize the logic of a legal argument. The reason the crime occurred, the real story the offender might tell, is nowhere to be found. In Stuart and Delisle's text, my criminal law book, R.v. Munro and Munro is lined up with the other cases in Chapter 3, "The Fault Requirement," nonchalantly placed under the heading, "Murder of a Police Officer." The placement may be logical but it seemed glaringly out of place to me.

I must say I know very little about my branch of the Munro family. My sister is the only Munro I have any kind of relationship with. Newspaper clippings, old court documents, and snippets of information pinched from private conversations have filled the 
gaps in my memory. My father was the oldest son of Lawrence and Francis Munro's eleven children. I derived this information from his death certificate, which I obtained from the registrar under false pretenses. It is a curious world that prevents a daughter from knowing where her father is buried. Of the eleven children in my father's family only three managed to avoid criminal sanctions. It was a family of habitual offenders leading self-destructive lives. The court did not ask why or how this happened. There will be some who attribute it to genetic predisposition, a hereditary propensity for violence. This answer frightens me, makes me wary of myself. But I'm not convinced it's the right answer. There was also chronic alcoholism and substance abuse, but how this got to be the norm in the family I cannot say. The better explanation is that it was a family that revolved around emotional and physical abuse. In the Munro household abuse often substituted for love. As a child my father had been beaten to the point of unconsciousness. It left him filled with hate and anger. Returning as an adult to that childhood home, he saturated its planks with gasoline and burnt it to the ground. A symbolic act, accomplishing nothing.

I often wonder what kind of person my father might have been if someone had tried to save him, or if anyone knew enough to try to save the children by removing them from harm. But no one did anything, and now nine siblings are criminal justice system darlings. The story of these children and the pain they must all bear is totally missing from the court records. It's ironic that the public and the government complain about the cost of maintaining the prison system, when their disregard helps create the people who inhabit it.

I remember walking the shiny halls of a correctional facility as a child, trying to stomp on the gleam reflected on the floor from the fluorescent lights overhead. I was oblivious to the fact that my father was in jail because he was a bad man. It was normal for me to speak to him through the awkward black phone hanging alongside the thick plastic wall separating us. Such things should never be normal, but then these things should never happen.

I now look upon R.v. Munro and Munro as a personal documentary, as a synopsis of a defunct lineage and my strained identity. Given that this case is of obvious personal significance, I have not tried to discuss its legal issues as would a law student. Instead of focusing on what is written in the judgment, I have been compelled by what it does not say. It may appear that I wish to shift the responsibility for my family's crimes to someone else. Perhaps I want to vindicate my father, or better, change the past. And I will always wonder whether a family of Munro children provided with a safe and loving home might not have averted the murder of police officer Sweet and many other crimes. I would have a father, and perhaps it is this unsatisfied desire that motivates my writing. Unfortunately, the past cannot be undone.

Note: The facts in this story are not completely accurate, but they reflect the author's understanding at the time it was written.

Reprinted with permission. 


\section{Distinguished, My Ass}

\section{Maureen Connolly}

\section{3M Teaching Fellow}

This narrative emerged from a workshop I had the privilege of attending as a $3 M$ Teaching Fellow. It reminds me that whatever encounters I have with students, colleagues, and subject matter, I must always nurture the self-reflective vigilance at the heart of making a difference as a teacher.

The first time I experienced depression was the summer of 1997, when my partner's two sons-ages nine and eleven, bright, precocious, and somewhat devious-spent that summer with us. Before this, depression was something that other people, without my considerable strength of character and willpower, experienced. Nothing prepared me for that swift slide into worthlessness and unrequited rage. The real kicker was that the boys weren't all that bad. They were just boys. I would go to the bathroom, turn on the shower and cry and cry. I would cry in other places and times as well and the summer unfolded into a succession of driving, cooking, cleaning, and laundry commercials interrupted by daily rituals of tears and self-loathing.

Fast forward six years. The phone rings in my office. I find myself gazing around my space as I contemplate the consequences of answering the phone. Shelves are piled with books and files, the gifts of students, mugs, figurines, pictures of my nephew. There are unpacked boxes that reach the ceiling stacked on the corner of my long desk. A dresser sits in the corner, containing my fitness and training clothes. CDs and tapes are piled near the phone, my briefcase is hanging open, a mouth for papers, memos, and more work to finish at home. My students wonder if I am moving in or moving out. This semester's course and committee files are my only anchor to the here and now. And I am here, now. $I$ am tired of here and now.

I feel the familiar and terrifying slide beginning. And it's not that things are that bad. It's a fairly regular semester, a fairly typical day. I answer the phone. It's Jill-her usual, damn chipper, high energy, see-the-good-in-every-moment self. She needs a title from me for the distinguished teaching award address I will give in May. I say to her, "How about the university's fucked and nothing that we do makes any difference?"

There is a long silence. Jill clears her throat.."Not a good time to ask you about this?" she asks. I wish that I had some magic button to stop the horrible ache in my throat and the tears in my eyes. I take off my glasses. The office fades to merciful fuzziness, the evidence of my incompetence temporarily, thankfully blurred.

"Give me a half hour," I tell her.

Reprinted with permission. 


\section{Author Note}

Thanks to Gerry Hess and Susan Olding for encouragement and helpful conversation, and to Jean Koh Peters, without whose wonderful collaboration I could not have written this chapter.

\section{References}

Allen, G. (Ed.). (1989). No more masterpieces: Short prose by new writers. Toronto, Canada: Canadian Scholars Press.

Connolly, M. (2005). Distinguished, my ass. In M. Lerch (Ed.), Making a difference/Toute la difference (pp. 31-32). Ontario, Canada: Society for Teaching and Learning in Higher Education.

Elbow, P. (1986). Embracing contraries: Explorations in learning and teaching. New York, NY: Oxford University Press.

Finkel, D. L. (2000). Teaching with your mouth shut. Portsmouth, NH: Boynton/Cook.

Goldberg, N. (1990). Wild mind: Living the writer's life. New York, NY: Bantam.

Lerch, M. (Ed.). (2005). Making a difference/Toute la difference. Ontario, Canada: Society for Teaching and Learning in Higher Education.

Munro, T. (2003). A family's criminal legacy. Legal Studies Forum, 27(1), 403-405.

O'Reilley, M. R. (1993). The peaceable classroom. Portsmouth, NH: Boynton/Cook.

O'Reilley, M. R. (1998). Radical presence: Teaching as contemplative practice. Portsmouth, NH: Boynton/Cook.

Palmer, P. J. (1998). The courage to teach: Exploring the inner landscape of a teacher's life. San Francisco, CA: Jossey-Bass.

Peters, J. K., \& Weisberg, M. (2005). Reflecting on our teaching 2005. Spokane, WA: Institute for Law School Teaching.

Saakvitne, K. W., \& Pearlman, L. A. (1996). Transforming the pain: A workbook on vicarious traumatization. New York, NY: W. W. Norton.

Tompkins, J. (1996). A life in school: What the teacher learned. New York, NY: Perseus.

Weisberg, M. (2003). Epilogue: When (law) students write. Legal Studies Forum, $27(1), 421-435$.

Weisberg, M., \& Peters, J. K. (in press). Experiments in listening. Journal of Legal Education. 